\title{
Sosyal Hizmet ve COVID-19: Salgın Sürecinde Sosyal Hizmet Mümkün Mü?
}

\author{
DOI: 10.26466/opus.829178
}

$*$

\author{
Ozan Selçuk * \\ * Dr. Öğr. Üyesi, Recep Tayyip Erdoğan Üniversitesi, Rize/Türkiye \\ E-Posta: ozan.selcuk@erdogan.edu.tr \\ ORCID: $\quad$ 0000-0002-2852-7491

\section{Öz}

COVID-19 salgını birey, aile, grup, topluluk ve toplumların hayatların alt üst ederken sosyal hizmetin de dahil olduğu tıp, hemşirelik, psikoloji, psikolojik danışmanlık gibi yardım mesleklerine olumsuz etki yapmıştır. Salgın dönemlerinin geleneksel yöntemlerinden biri olan karantina uygulama temelli bir meslek ve disiplin olan sosyal hizmette yüz yüze irtibatı sinırlamıştır. Sinırlı temasın olduğu bu dönemde insan hakları ve sosyal adalet ilkelerine dayanan sosyal hizmet uygulamasının gerçekleştirilmesi zorlaşmıştır. Bilgi, beceri ve değer temelinde uygulama yapan sosyal hizmet uzmanları COVID-19'un etkilerini azaltma noktasında mikro, mezo ve makro boyutlarda faaliyetlerini gerçekleştirmektedir. Salginın etkileri karşısında sosyal hizmetin gerçekleştirilmesine ilişkin zorluklar ile sosyal hizmet uzmanları açısından ortaya çıkan yeni rol ve sorumlulukların tartışıldığı bu çalışmanın amacı farkl uygulama alanlarında karşılaşılan zorlukların görünür kılınmasıdır. Salgin gibi biyolojik afetlerde yardım mesleklerinin öneminin daha da anlaşıldı̆̆ı bu dönemde uygulamaların daha yenilikçi hale gelmesi ve salginın yıkıcı etkileri karşısında sosyal hizmet uzmanlarının teşvik, önleme ve duyarlılık açısından rol ve sorumluluklarının olması gerekmektedir. Bu yolla COVID döneminde sosyal hizmet uzmanlarının uygulama alanlarında mevcut rol ve sorumlulukları genişletilmektedir.

Anahtar Kelimeler: sosyal hizmet, COVID-19, salgin, sosyal hizmet uygulamasl. 


\title{
Social Work and COVID-19: Is Social Work Possible During Pandemic?
}

\begin{abstract}
While the COVID-19 pandemic has exacerbated the lives of individuals, families, groups, communities and societies, it had a negative impact on helping professions such as medicine, nursing, psychology, psychological counselling, including social work. Quarantine, one of the traditional methods of pandemic periods, limited face-to-face contact in social work, which is a practice-based profession and discipline. In this period of limited contact, social work practice based on human rights and social justice principles has become difficult. Social workers who practice on the basis of knowledge, skills and values carry out their activities in micro, meso and macro dimensions to reduce the effects of COVID-19. The aim of this study, which discusses the difficulties in the conduct of social work in the face of the effects of the pandemic, and the new roles and responsibilities that emerge for social workers, is to make visible the difficulties encountered in different practice fields. During this period when the importance of helping professions in biological disasters such as pandemic is understood deeply, it is necessary that the practices become more innovative, and social workers have roles and responsibilities in terms of encouragement, prevention and sensitivity in the face of the destructive effects of the pandemic. In this way, the existing roles and responsibilities of social workers in the practice fields of the COVID period are expanded.
\end{abstract}

Keywords: social work, COVID-19, pandemic, social work practice, child welfare. 


\section{Giriş}

Birleşmiş Millet Kalkınma Programı, COVID-19 krizinin bir sağlık krizinden daha fazlası olduğu ve toplumlar ile ekonomileri temelinden sarstığı konusunda devletleri uyarmaktadır (UNDP, 2020). Geriye dönük tanımlamalara göre ilk vakanın 8 Aralık 2019 tarihinde Hubei (Çin) eyaletinin Wuhan şehrinde ortaya çıkan ve 31 Aralık 2019 tarihinde Dünya Sağlık Örgütü'ne (WHO) Çinli yetkililer tarafından 27 vaka ve 0 ölüm olarak bildirilen yeni tip Koronavirüs (COVID-19) hastalığ 1 tüm dünyayı etkisi altına almıştır (Wu ve Mcgoogan, 2020). 7 Ocak 2020 tarihinde Çinli bilim insanları tarafından yeni tip Koronavirüs olarak tanımlanan bu hastalık WHO tarafından "uluslararası öneme haiz halk sağlığı acil durumu" olarak ilan edildiği 30 Ocak 2020 tarihinden bugüne kadar 216 farklı ülke tarafından raporlanan hastalık bulaşan kişi sayısı 6 Kasım 2020 itibariyle 48,2 milyondur (WHO, 2020). Yine bu dönemde günlük vaka sayısının 250 binin üzerinde olması bu hastalığın halen yayılma gösterdiğinin ve durumun ciddiyetini koruduğunun en önemli göstergesidir. Tüm dünyaya yayılan bu hastalık Dünya Sağlık Örgütü tarafından "salgın" olarak tanımlanmaktadır. Dolayısıyla salgına karşılık vermek hem Dünya Sağlık Örgütü gibi uluslararası düzeyde hem de ulusal düzeyde bir eylem gerektirmektedir. Bu eylemin en ön safında sosyal hizmet gibi insani hizmet meslekleri yer almaktadır.

Sosyal hizmet, küresel tanımında yer aldığ 1 üzere sosyal değişme ve gelişmeyi teşvik eden uygulamalı bir disiplin ve meslektir (IFSW, 2014). Uygulama temelli bir meslek olarak sosyal hizmet müracaatçlarıyla doğrudan temas kurmak durumundadır (Bride, 2007). Dolayısıyla yüz yüze irtibat sosyal hizmet uygulamasının ayrılmaz bir parçasıdır. Ancak koronavirüs karantinası, alanda çalışan uzmanlar için önemli zorluklar ortaya çıkarmıştır (de Jonge, Kloppenburg ve Hendriks, 2020). Sinırlı temasın olduğu dönemde özellikle çocukların sağlığı ve güvenliği konusu insan hakları ve sosyal adalet temeline dayanan sosyal hizmet için önemli sorun alanlarından biri olarak karşımıza çıkmıştır. Sosyal hizmet müdahalesinde planlı değişim süreci basamaklarından özellikle bağlantı kurma ve ön değerlendirme aşamaları temasın en yoğun olduğu aşamalardır. Vakaların değerlendirilip sonuçland1rılması ve bunun sonucunda koruma hizmetlerinin sunulması için elzem olan örneğin çocuk koruma değerlendirmesi, ev ziyaretleri gibi faaliyetlerin gerçekleştirilememesi aile içi ilişkilerin ve risklerin değerlendirilmesini 
imkânsız kıldığı gibi vakaların sonlandırılmasını da ya engellemekte ya da uzatmaktadır (Swazoom, 2020). Salgın koşullarından dolayı ailelerin de görüşme ve ziyaretleri kabul etmemesi, endişelenmesi ve salgının üzerlerinde yarattığ1 sosyal, psikolojik ve ekonomik baskı şartları daha da zorlaştırmıştır.

Bu dönem diğer taraftan mesleki standartlar, mesleki etik ve mesleğin doğası gereği zorlukların üstesinden gelmek durumunda olmak sosyal hizmeti salgın döneminde diğer sağlık alanındaki meslekler gibi değerli bir meslek haline getirmiştir. Öte yandan okulların kapalı olmasından dolayı eğitimin uzaktan verilmesi, ebeveynlerin bu sürece dahil olmaları, diğer taraftan da zorlu koşullar çocukların içinde bulundukları şartları daha riskli hale getirmiştir. Bu örnekte olduğu gibi insan hakları ve sosyal adalet ilkelerinden gücünü alan sosyal hizmet müdahaleleri salgın sürecinde derinlemesine tartşılması gereken konular olarak karşımıza çıkmaktadır.

Salgın dönemi literatürü incelendiğinde sosyal hizmet için bir halk sağlığı rehberinin olmaması sahada çalışan sosyal hizmet uzmanları için salgın döneminde hem müracaatçılar için hem de kendileri için risk oluşturmaktadır (Dominelli, 2020; Banks ve diğ., 2020a; Ferguson ve diğ., 2020). Sinırlı temasın olması aile ziyaretlerini sınırlandırmakta ve ailelere sunulan destekleri minimum düzeye indirmektedir. Sınırlı iletişim ayrıca ilişkileri ve risk değerlendirmesi yapmayı da zorlaştırmaktadır. Bu durum karşısında sosyal hizmet uzmanları daha yaratıcı olmakta ve teknolojik araçları daha yoğun bir şekilde kullanmaktadır. Vaka dosyalarının da bu nedenle azalmaması da bu dönemde sosyal hizmet uzmanı olmanın zorluklarından birkaçı olarak gösterilebilir. Salgın dönemi sosyal hizmet literatürü yakından incelendiğinde ayrıca sosyal hizmet uygulamasına ilişkin çok az çalışmanın yapıldığı ve bu çalışmaların da daha çok etik zorluklar üzerinde yoğunlaştı̆̆ görülmektedir (Banks ve diğ., 2020b; Dominelli, 2020; Miller ve Lee, 2020).

Bu bilgilerden hareketle bu çalışmanın amacı salgın sürecinde yüz yüze temasa dayalı bir meslek olan sosyal hizmet uygulamalarının farklı uygulama alanlarında nasıl gerçekleştirildiğini ortaya koymak ve yaşanan zorlukları görünür kılmaktadır. Bu bağlamda sosyal hizmet uzmanlarının yaşadığı zorluklar literatürde yapılan araştırmalardan elde edilen bulgular ışı̆̆ında tartısılmıştır. Bu tartışmalar bizleri sosyal hizmetin salgın gibi biyolojik afetlerde ne denli önemli bir meslek alanı olduğu ve bu yüzden de uygulamalarını daha yenilikçi hale getirmesi sonucuna götürmektedir. 
Diğer bir bulgu ise salgının yıkıcı etkileri karşısında uzmanların teşvik, önleme ve duyarlılık açısından rol ve sorumluluklarının olduğudur.

\section{Salgın Döneminde Sosyal Hizmet Açısından Yaşanan Zorluklar}

Salgın dönemi kuşkusuz sosyal hizmet uzmanlarını müdahalelerini gerçekleştirmekten alıkoymamış ve hatta salgın kurallarına uygun alternatif yöntemler arayışına girmiştir. Bu süreçte ihtiyaç sahibi birey ve ailelere destek veren sosyal hizmet uzmanları yardım boyutunu geliştirmiştir. Salgın döneminin en zorlu şartlarından biri karantina ve bundan dolayı getirilen yasaklardır. Bu yasaklar birey, aile, topluluk ve toplumların yaşamlarını tahrip etmiş ve var olan zayıflıkları ve baskıyı daha da ağırlaştırmıştır (Miller ve Lee, 2020). Etik ve değer temeline sahip sosyal hizmet mesleği de salgının yarattı̆̆ bu psikolojik, sosyal ve ekonomik sorunlara karşı çözümler üreterek dezavantajlı grupları korumaya kendini adamıştır. Etik ilke ve değerlerinde tanımlandığı üzere sosyal hizmet insan refahını arttırmayı ve insanların temel ihtiyaçların karşılamaya yardım eden bir meslektir. Dolayısıyla sosyal hizmet, COVID-19 hastalığının olumsuz etkilerini azaltmada önemli roller üstlenmiştir.

Salgın döneminin sosyal hizmet mesleği açısından yarattı̆̆ en büyük sorunların başında etik zorluklar gelmektedir. Salgın "güç ilişkilerini ve yapısal eşitsizlikleri ön plana çıkarmış ve yoksulluğun, rrkçllğın ve diğer adaletsizliklerin etkilerini doğrudan ele alan eleştirel bir uygulama etiği için olanaklar açmıştır" (Featherstone ve diğg., 2018; Keddell, 2020). Salgında ortaya çıan etik zorluklar sosyal hizmet mesleği için yeni firsatlar yarattı̆̆ açıktır. Bu dönemde daha destekleyici olan uzmanlar daha çok ailelerin gündelik ihtiyaçlarını karşılamaya odaklanmışlardır. Yapılan bir araştırmaya katılan sosyal hizmet uzmanları salgın döneminde yeni vaka sayılarının düştüğünü ve bunun yerine gıda bankasına yönlendirme, elektrik ve gaz ile ilgili problemlerle daha fazla ilgilendiklerini ifade etmişlerdir (Ferguson ve diğ., 2020). Bu da aslında uzmanların rollerinin yeniden tanımlanması değil bakım rollerini yerini getirdikleri anlamına gelmektedir.

Sosyal hizmet uygulamasına ilişkin COVID-19 sürecinde sosyal hizmet uzmanlarının yaşadığı sorunların ortaya konulmasına ilişkin yapılan bir araştırmada katılımcıların en çok gündeme getirdiği en yaygın sorunlar ara- 
sinda fiziksel mesafe gereksinimlerinin, özellikle de sosyal hizmet uzmanlarının ve/veya müracaatçlların aile üyelerinin varlığı nedeniyle mahremiyetin sağlanamaması ve bu yüzden telefon ve internet yoluyla evden "uzaktan çalışma" gibi zorluklar bulunmaktadır (Banks ve diğ., 2020b). Araştırmada ayrıca bazı müracaatçların teknolojiye erişememesi veya teknolojiyi kullanamaması gibi sorunlar da ortaya çıkmıştır. Sosyal hizmet uzmanlarının görüntülü görüşmelerde zorluk yaşadıkları, bir evdeki koşulları değerlendiremedikleri veya insanları göremeden, göz teması kuramadan veya yaşam alanını birinci elden deneyimlemeden ve mevcut ilişkilerin doğasını tespit edemedikleri ortaya çıkmıştır (ss. 572-574). Bu durum esasen yüz yüze gerçekleştirilen görüşmeler için de geçerli olmaktadır. Müracaatçlların kullandığı kişisel koruyucu ekipmanlar iletişimi, sözlü olmayan ipuçlarını alma, empati kurma gibi becerilerini kullanma olasılığını engelleyebileceği de bir gerçektir.

COVID-19 salgınının sosyal hizmet uzmanlarının üzerinde korku, endişe, baskı, güvenlik kaygısı, etiketlenme ve öz-bakım gibi zorluklar da ortaya çıkarmıştır (BASW, 2020). Salgın gibi süreçlerde bu zorluklara maruz kalma olasılığ 1 yüksek olmasına karşın normal bir durumdur. Ruh sağlığı ve psikososyal iyilik halinin etkilendiği bu dönemde uzmanın yaptığı işten zevk duymamasına veya görevini tam manasıyla yerine getiremediği hissi yaşamasına neden olabilmektedir. Fiziksel sağlığı korumanın da önemli olduğu bu dönemde aşırı yorgunluk hissi, yeme bozukluğu, fiziksel aktivite yetersizliği gibi zorluklarla da karşılaşılabilmektedir. Banks ve arkadaşları (2020a) tarafından sosyal hizmet uzmanlarıyla yapılan bir araştırma korku ve endişe yaşayan uzmanların virüsten ölenler ve kötü koşullarda yaşayan insanlar karşısında daha fazlasını yapamamaktan ötürü suçluluk ve utanç duyduklarını ortaya koymaktadir.

COVID-19 süreci sosyal hizmet uzmanları için mesleki standartlar doğrultusunda müracaatçıların ihtiyaçlarını karşılamayı zorlu hale getirmiştir. Algılanan sosyal destek üzerine yapılan bir araştırma fiziksel yakınlıkla ilgili mantıklı ve sorumlu karar verme konusunda sosyal hizmet uzmanlarının yeterli sosyal destek göremediklerini ortaya koymaktadır. Bunun nedeni olarak katılımcılar, çalışmaları için yeterli koruyucu ekipmanların eksikliğini göstermişlerdir (Banks ve diğ., 2020a).

Salgın döneminde ülkelerde en yetkili organlar olan sağlık bakanlıkları tarafından hazırlanan rehberler ve broşürler halk sağlığını koruma adına tüm 
medya platformlarından toplumun istifadesine sunulmuştur. Ancak uygulamalı mesleklerde bu rehberlerin önemi daha fazla ortaya çıkmaktadır. Sınırlı temasın ve fiziksel mesafenin olduğu dönemde sosyal hizmet gibi yüz yüze iletişimin uygulamanın temelini oluşturduğu mesleklerde salgına özel uygulama rehberlerinin yetkili otoriteler tarafından sosyal hizmet uzmanları için ortaya konması elzemdir. Bu yolla ortaya çıkması muhtemel mesleki zorlukların bertaraf edilmesi mümkün olacaktır. Sosyal hizmet uzmanları diğer yardım meslek elemanları gibi COVID-19'un hizmet sundukları müracaatçı grupları ile aileler ve toplumların refahlarıla ilgilenmektedir ve bu konuda mesleki girişimlerde bulunmaktadır. Mesleğin COVID-19'u önlemede en ön safta bulunduğu olgusundan hareketle uzmanların salgının önlenmesinde bireylere güvenilir kaynaklardan doğru bilgiyi sunmaktadır. Bu halk sağlığını krizini önlemede ise kuşkusuz ki güvenilir bilgilerin yer aldığı rehberler büyük önem taşımaktadır. Bu rehberler bir yandan halkı bilgilendirme amacı taşırken diğer yanda hem toplumu hem de sosyal hizmet uzmanlarını koruma amacı gütmektedir. Bu süreçte Amerika'da Ulusal Sosyal Hizmet Uzmanları Birliği (NASW), İngiltere'de Britanya Sosyal Hizmet Uzmanları Birliği (BASW) ve Türkiye'de Sosyal Hizmet Uzmanları Derneği (SHUDER) önemli kaynaklar hazırlamışlardır. Bunun yanı sıra gerçekleştirilen çevrimiçi seminerlerle sürekli güncel bilgi akışı ve karşılaşılan zorlukların tartş̧ılması mesleki etkinliklerin geliştirilmesi açısından önemli fırsatlar sunmuştur.

Sosyal ve ekonomik etkileri derin olan COVID-19 ayrica sosyal mesafe tedbirleriyle yaşayış biçimimizi ve sosyal etkileşimlerimizi derin bir şekilde etkilemiştir. Bu değişimden etkilenen gruplardan biri de okul çağındaki çocuklardır. COVID-19 hastalığı açısından her ne kadar belirtiler göstermedikleri veya hastalığın hafif seyrettiği ortaya konsa da (Wu ve McGoogan, 2020; Lu ve diğ, 2020) çocuklar en az etkilenen popülasyon olmadığı önemle vurgulanmalıdır. Akran ilişkilerini kaybetmeleri, okulun mevcut psikososyal faydalarından uzak kalmaları, eğitimin çevrimiçi verilmesi nedeniyle akademik performans açısından olumsuz etkilenmeleri ve diğer riskler kadar odaklanılması gereken bir nokta olan fiziksel aktivite eksiklikleri çocukların iyilik halini etkileyen riskler olarak karşımıza çıkmaktadır (Teo ve Griffiths, 2020; Wang ve diğ., 2020). Bu riskler kuşkusuz ki çocukların fiziksel, duygusal ve ruh sağlıklarının önündeki tehlikelerdir. Salgının sosyal ve ekonomik etkileri eve kapanan, çocuklarıyla daha fazla vakit geçiren ve evde öğretim yönteminden ötürü çocuklarının dersleriyle ilgilenen ebeveynlerin üzerindeki 
baskı aile içi yıkıcı davranışlarla sonuçlanabilmektedir. İşsizlik, toplumsal cinsiyet bağlamında aile içi roller ve aile içi şiddet ev içi ilişkileri daha da yıkıc hale getirmektedir. Bu durum da her ne kadar her seviyedeki ailelerde ortaya çıkabilecek bir risk olsa da sosyoekonomik olarak düşük seviyedeki ailelerde ihmal ve istismar daha fazla ortaya çıkmaktadır (Lindo ve diğ., 2013). Bu nokta sosyal hizmet uzmanlarının çocuk koruma bağlamında çok daha dikkatli olmalarını ve savunuculuk rollerini kullanarak salgın şartlarına rağmen çocuk koruma hizmetlerinin aksamamasını temin etmeleri gerektirmektedir.

Yapılan bazı çalışmalar doğal afet gibi dönemlerde çocuk koruma vaka sayılarının önemli derecede düştüğünü (Seddighi ve diğ., 2019; Rubenstein ve Stark, 2017; Flynn-O'Brien ve diğ, 2016; Nelson ve diğ., 2011) ortaya koysa da çocuklara, yetişkinlere ve ailelere yönelik sosyal hizmet modellerine sevk, karantina bittiğinde ortaya "gizli zararlar" ve birikmiş ihtiyaçların çıkacağına dair öngörüler bulunmaktadır. İngiltere'de Büyük Britanya Sosyal Hizmet Uzmanları Birliği (BASW) tarafından yapılan bir çalışmaya katılanların \%85'inden fazlası, bu durumun çocukların okula geri döndüğü Eylül ${ }^{1}$ ayında etkili olmaya başlamasını beklemektedir. İngiltere'de yüz yüze eğitimin Eylül ayında başlayacağı ve okullarda uygulanan sosyal hizmet aracıllğıyla salgının çocuklar üzerindeki etkilerinin tespit edileceği öngörüsünde bulunulmaktadır (BASW, 2020). Ülkemizde salgının çocuklar üzerinde risk yaratıp yaratmadığı ancak okul rehberlik servisleri ve öğretmenler tarafından ortaya çıkarılması mümkün olacaktır. 2020-2021 eğitim ve öğretim yılı ülkemizde belli şehirlerde belli sınıf düzeylerinde kademeli olarak yüz yüze verilmeye başlanmıştır (MEB, 2020). Dolayısıyla 2021-2022 akademik yılında mevzubahis risklerin daha net bir şekilde ortaya çıkacağı öngörülmektedir. Bu bulgudan da anlaşılacağı üzere toplum içerisinde salgın temelli sosyal sorunların tamamen ortaya çıkmadığı ve bu durumun sosyal hizmet mesleğini bekleyen önemli gelişmelere gebe olduğunu göstermektedir.

Değer temelli bir meslek olan sosyal hizmet tüm etkinliklerinde baskı ve ayrımcilığa karşı duruş sergilerken bunu uygulamalara da yansıtmaktadır (Dominelli, 2020). Baskı karşıtı sosyal hizmet uygulaması, kültürel açıdan duyarlı uygulamalara ulaşmak için insanların değerlerinin, sosyal normlarının ve aile düzenlemelerinin tam olarak anlaşılmasının çok önemli olduğunun

\footnotetext{
${ }^{1}$ Söz konusu çalışma Mayıs 2020 tarihinde gerçekleştirildiğinden öngörü Eylül 2020 tarihi için yapılmıştır.
} 
savunularak sosyal hizmet uygulamasını geliştirilmesi olarak tanımlanmaktadır (Laird, 2008). Bu uygulama modeli uzmanların bir yandan müracaatçılarının ve kendi sağlıklarını koruduklarından diğer yandan da virüsün kendileri tarafından yayılmadığından emin olmalarını gerektirmektedir. Bu durum sosyal hizmet uzmanlarının sahip olduğu mesleki becerilerinin salgın şartlarına uyumlu hale getirmelerini zorunlu kılmaktadır. Bu durum da baskı altındaki uzmanların mesleki etkinliklerini yerine getirmede daha fazla stres sahibi olmalarıyla sonuçlanmaktadır.

\section{Sosyal Hizmet Uzmanlarının Salgın Döneminde Ortaya Çıkan Rol ve Sorumlulukları}

Daha önce de tartışıldığı üzere sosyal hizmet uygulama odaklı bir meslektir ve temelinde müdahale bulunmaktadır. Salgın gibi doğrudan temasın sınırlandığ 1 ve hatta kısitlandığ dönemlerde de bu süreç zorlu olsa da devam etmektedir. İnsanların salgından bağımsız gereksinimlerinin yanı sıra salgın kaynaklı yaşadıkları sosyal ve ekonomik zorluklar ve gereksinimleri sosyal hizmete daha fazla sorumluluklar yüklemektedir. Bu yüzden sosyal hizmet uzmanlarının salgın döneminde daha fazla rol ve sorumluluklar üstlenmesi gerekmektedir. Bu bölümde sosyal hizmet uzmanlarının salgın döneminde üstlendiği yeni rol ve sorumluluklar tartışlacaktır.

COVID-19 krizinde sosyal hizmet uzmanları daha önceden görülmemiş ve deneyimlenmemiş bir durum karşısında krizin yol açtığı sağlık, sosyal ve ekonomik boyutlara hızla adapte olmakta ve karşılık vermektedir (Pentini ve Lorenz, 2020). Bu süreçte müracaatçlarına doğrudan hizmet sunarak uzmanlar bütüncül rol oynamaktadır. Toplumda oluşan yeni taleplere ve beklentilere karşılık vererek hizmetlerin kesintisiz sunulması için çaba harcamaktadirlar.

Sosyal hizmet, maksimum düzeyde yardım etme işlevi gören bir meslektir (Sheafor ve Horejsi, 2014). Bu bağlamda sosyal hizmet uzmanlarının COVID-19 salgını sürecinde müracaatçılara yardım etmek üzere öncelikli olarak bu hastalığın nedeni ve belirtileri hakkında asgari düzeyde fikir sahibi olmaları önemlidir. Dünya Sağlık Örgütü'nün bu hastalık hakkındaki açıklamalarına göre COVID-19 aşağıdaki belirtileri sıklıkla gösteren kişilerde görülmesi yüksek ihtimaldir (WHO, 2020): 
- $\quad$ Öksürük

- 38 derece ve üzeri ateş

- Nefes darliğ1

Bu belirtileri gösteren bireyler, genellikle testi pozitif çıkan birey ya da bireylerle 1-2 metreden yakın ve 10 dakikadan fazla süre ile yakın temas kurmalarından, enfekte olmuş alanlarda bulunmalarından, kuluçka döneminde olan enfekte bir bireyle temasından veya enfekte olmuş ortamlardaki yüzeylerle temasından dolayı enfekte olmaktadırlar. Bu bilgi ve bulgular sosyal hizmet uzmanının hem kendisini hem de müracaatçısını virüse karşı koruması ve bilgilendirmesi açısından önemlidir. Salgın koşullarında öz bakım ve koruma esastır (Dominelli, 2020). Sosyal hizmet uzmanları olarak hem Dünya Sağlık Örgütü (covid19.who.int) hem de Sağlık Bakanlığı'nın (covid19.saglik.gov.tr) Koronavirüs özel sayfaları sürekli olarak takip edilmelidir.

Görüşme, sosyal hizmet mesleğinin odağını oluşturan mesleki bir etkinliktir (Kadushin ve Kadushin, 2016). Müracaatçıya yardım sunmada insan ilişkilerinin önemi teşvik edilmektedir. Yüz yüze gerçekleştirilen mesleki etkinliklerde güvenli, dürüst ve empatik bir ilişki kurulması müracaatçıya etkin hizmet sunumu içi oldukça elzemdir. Ancak salgın gibi kısıtlama tedbirlerinin yaygın olduğu süreçte sosyal hizmet uzmanlarının iyi bir ilişki kurma ve bu ilişkiyi sürdürmesi oldukça zordur (Deng, 2020; Redondo-Sama ve diğ., 2020). Ayrıca görüşmelerde gizliliğinin korunması ilkesi de unutulmamalıdır. Bu yüzden çevrimiçi araçlarla gerçekleştirilecek olan görüşmelerde bu ilkelerin aynı şekilde uygulanması esastır.

Sosyal hizmet uzmanları, baskı karşıtı uygulama yöntemiyle müracaatçılarla birlikte toplumsal sınıflara ve yapısal eşitsizliklere karşı müdahalelerini gerçekleştirir (Dominelli ve Campling, 2002). Sosyal hizmet uzmanları virüsten kendilerini korurken aynı zamanda müracaatçıların da kendi sağlıklarını korumaları noktasında sorumlulukları bulunmaktadır. Sosyal hizmet uzmanları bunu yaparken insan onuruna saygıyı esas alır ve başkalarına zarar vermeme ilkesine riayet eder. Salgın koşullarının gerektirdiği önlemleri içeren rehberlere uyum sağlar ve bu rehberlerde yer alan tedbirlere uyar.

Salgın sürecinde sosyal hizmet uzmanları sadece kendi rol ve sorumluluklarını yerine getirmez aynı zamanda tıbbi bakım sunan sağlık çalışanlarına yardım sunma görevleri de vardır. Aile refahı, çocuk koruma ve benzeri alanlarda şu sorumlulukları yerine getirmektedir (BASW, 2020): 
- Hizmetlere yönlendirme (tibbi, vb.)

- Toplumsal düzeyde kaynakları bulma ve harekete geçirme

- Toplum sağlığı eğitimi yoluyla insanlara kendilerini ve çevrelerini nasıl koruyacaklarını anlatma

- Korku ve kaygı gibi duygusal ihtiyaçları karşılamada bireyleri destekleme

- Kayıp ve yas danışmanlığı sağlama

- Bireylere kendilerini nasıl güvenli ve sosyal mesafede tutacakları konusunda yardimci olma

- Insan hakları ve sosyal adaleti temin etmede bireylere savunuculuk yapma

- Devletin salgın sürecindeki tedbirleri ve politikalarının bireyler tarafından anlaşılabilir olması için önlemler alma

- Sosyal hizmet uzmanları olarak kendi sağlık ve iyilik halini gözetme

- Çocukları okullarda destekleme

- Çocuk ve ailelere COVID-19 test merkezlerine erişimlerinde destek olma

Sosyal hizmet uzmanları, bu rol ve sorumlulukları yerine getirirken maske, mesafe ve temizlik süreçlerine azami şekilde dikkat etmeli ve böylece öz bakım ve psikolojik sağlamlık konusunda kendisini sürekli olarak desteklemelidir. Salgının neden olduğu korku ve endişe duyguları karşısında uzmanların kendileri, aileleri, müracaatçılar ve toplum için kendilerine mümkün olduğunca yardım etmeleri ve öz bakım becerilerini yükseltmeleri gerekmektedir. Ayrıca sağlıklı olmayan baş etme becerilerine (sigara, alkol vb.) başvurmamaları gerekmektedir. aşı çalışmalarının uzun zamanlar alacağı öngörüsüyle koronavirüs maratonunda mücadeleye devam etmek gerekmektedir. Bu noktada BASW (2020) tarafından salgın sürecinde sosyal hizmet uzmanları için şu şekilde öneriler sunulmaktadır:

- Günlük olarak iyi olup olmadığını kontrol et,

- Raporlu ve izinli olduğun günleri ya da tatil günlerini iyi değerlendir ve ihmal etme,

- Ev hobileri, spor yapma, arkadaş/aile ile konuşma ve uyku gibi kişisel rutinlerini sürdür,

- Müracaatçılarına ve işine olan yaklaşımlarında salgına özel koşullardan dolayı esnek ol,

- Sorumluluklarınız için açıkça yetkin olduğundan emin ol ve daha fazla ek iş üstlenemiyorsan "hayır" de, 
- Mesleki ve kişisel olarak açık bir destek sistemi tanımla; bunun zor zamanlarında yalnız olmadığın anlamına geleceğini unutma,

- "Işimi yine de yapıyorum" kültüründen kaçın ve gerektiğinde yardım iste,

- Kendine düşünme zamanı ayır ve bu düşüncelerini yazmayı ya da kaydetmeyi düşün,

- Bir şey hakkında emin değilsen sorular sor,

- Haberlere ve sosyal medya paylaşımlarına olan maruziyetini azalt,

- Süpervizyon al,

- Mizahın destekleyici olarak uygun bir şekilde kullanımını salgın ortamında bile göz ardı etme,

Karantina sürecinin yüz yüze görüşmeyi etkilemesinin bir sonucu da virüsün yayılımının önlenmesi için uzmanın müracaatçıyla geçirdiği zamanın azalmasıdır (Ferguson ve diğ., 2020). İyi bir sosyal hizmet müdahalesinin ilk iki aşaması olan müracaatçı ile karşılaşma ve ön değerlendirme aşamalarında müracaatçı ve çevresinin derinlemesine ele alınması açısından önem arz etmektedir. Müracaatçyla iletişimde video konferans veya telefon imkanlarının kullanılarak yapılabilmektedir. Bu noktada hibrit uygulama yöntemi en uygun çözüm olarak kullanılabilir. Salgın koşullarından ötürü temasın sınırlandığı süreçte müracaatçı ile olan iletişim ve ilişkide farklı iletişim yöntemlerinin birbiriyle entegrasyonu sağlanmalıdır. Açık havada maske ve mesafe kurallarına riayet ederek yüz yüze görüşme, cep telefonunda görüntülü görüşmeye imkân veren uygulamalarla iletişim kurma bu hibrit yaklaşıma örnek gösterilebilir. Müracaatçılla güvene dayalı bir ilişkinin kurulması salgın öncesi döneme göre zor olsa da uzmanlar olarak daha fazla görüşme yapma suretiyle bu zorluk aşılabilir. İlişki temelli uygulamanın birey ve aileler üzerinde olumlu etkiye sahip olduğu ve bireylerin gelişmesinde ve değişmesinde onlara destek olduğu açıtır (Ferguson ve diğ, 2020).

\section{Sonuç ve Öneriler}

Bu çalışmada sosyal hizmet uzmanlarının salgın döneminde yaşadığı zorluklarla ilgili mesleki uygulama ve etik ilkeler çerçevesinde literatürde yer alan araştırma bulgularına yer verilmiş ve bu zorluklar derinlemesine tartışılmıştır. Salgın gibi sınırlı temasın olduğu şartlarda toplum refahını arttırmada sosyal hizmet gibi profesyonel yardım mesleklerinin önemi daha da ortaya 
çıkmıştır. Salgın dönemi kuşkusuz sosyal hizmet uzmanlarını müdahalelerini gerçekleştirmekten alıkoymamış ve hatta salgın kurallarına uygun alternatif yöntemler arayışına girmiştir.

Yeni Koronavirüs salgınının neden olduğu karantina ve sınırlı temas şartlarından etkilenen sosyal hizmet bu dönemde mesleki etkinliklerini yerine getirirken birçok zorlukla karşı karşıya kalmıştır. Etik zorlukların yaşanması; kısıtlamalardan dolayı ev ziyaretlerinin yapılamaması; uzaktan çalışma sonucu mahremiyet sorunları; sosyal hizmet uzmanlarının yaşadıkları korku, endişe ve baskı; uzmanlara özel uygulama rehberlerinin eksikliği; salgın şartlarının henüz ortadan kalkmamasından ötürü salgın sonrası ortaya çıkması muhtemel gizli zararlar; toplumsal cinsiyet temelli konular; müracaatçların karşılaştığı hak ihlallerine verilecek karşılık; baskı ve ayrımcılığa karşı savunuculuk rolünün yerine getirilmesi gibi zorluklar başlıca konular arasında yer almaktadır.

Diğer taraftan bu yaşanan zorluklar sosyal hizmetin etkin bir şekilde uygulanmasının önünde engeller oluştururken bu engellere karşı sosyal hizmet uzmanları için yeni rol ve sorumluluklar ortaya çıkmıştır. Bu rol ve sorumluluklar uygulama temelli bir meslek olan sosyal hizmet için mikro, mezo ve makro düzeylerde girişimlerde bulunmaya sevk etmiştir. Bu girişimler arasında etik zorlukların üstesinden gelmek; yeni koşullara huzla uyum sağlamak; COVID-19 hastalığının belirtileri, yaygınlığı, tedavi süreçleri ve hastalıktan korunma gibi konular hakkında asgari bilgiye sahip olma, müracaatç1ları bilgilendirme ve bunun için salgın döneminde uygulama alanlarına özgü (çocuk, yaşlı, hastane) mesleki uygulama rehberleri oluşturma; baskı karşıtı uygulama yapma; sektörler arası işbirliğini en üst düzeye çıkarma; kendileriyle ilgili öz-bakım ve psikolojik sağlamlık konularında çalışmalar yapma; müdahale süreçlerinde uzmanların dijital becerilerinin arttırılarak hibrit uygulama yöntemi ve kısıtlamaların yol açması muhtemel hak ihlallerine karşı hak temelli uygulamayı benimseme gibi boyutlar bulunmaktadır. Konuya mesleki örgütler açısından bakıldığında ise Türkiye'de sosyal hizmet için önemli bir mesleki örgütlenme olan Sosyal Hizmet Uzmanları Derneği'nin (SHUDER) mesleki etik ilke ve değerlerin yeni bağlamlara nasıl uygulanacağı, dijital çalışmanın etik çıkarımlarının ve yeni tarz risk değerlendirmelerin neler olacağı konusunda hazırlıklı olmaları, sürekli bilgilendirme yapmaları ve sosyal politikayı etkilemek hem sosyal hizmet mesleğini hem de uzmanların mesleki etkinliklerini önemli derecede arttıracaktır. 


\section{EXTENDED ABSTRACT \\ Social Work and COVID-19: Is Social Work Possible During Pandemic?

\author{
Ozan Selçuk \\ Recep Tayyip Erdoğan University
}

Whilst the COVID-19 pandemic has exacerbated the lives of individuals, families, groups, communities, and societies, it harmed helping professions such as medicine, nursing, psychology, psychological counseling, including social work. Quarantine limited face-to-face contact for social work, which is a practice-based profession and discipline. In this period, social work practice based on human rights and social justice principles has become difficult.

Undoubtedly, the pandemic period did not prevent social workers from performing their interventions and even seeking alternative methods following the pandemic measures. In this process, social workers have developed the helping dimension that supports individuals and families in need. One of the most strenuous conditions of the pandemic is quarantine and the prohibitions imposed. These prohibitions have destroyed the lives of individuals, families, communities, and societies and aggravated the existing weaknesses and oppression. The pandemic emphasized power relations and structural inequalities and posed significant challenges to a critical social work practice ethic that directly addresses the effects of poverty, racism, and other injustices. The COVID19 pandemic has also raised challenges, such as fear, anxiety, pressure, security anxiety, labeling, and self-care, on social workers. The COVID-19 process has made it difficult for social workers to meet the clients' needs in line with professional standards. School-age children are one of the groups affected during the pandemic period.

Losing peer relationships, staying away from the existing psychosocial benefits of the school, a low academic performance due to online education, and loss of physical activity are the common risks affecting child welfare. These risks are undoubtedly dangerous to children's physical, emotional and mental health. Although some studies show that the number of child protection cases decreased significantly in periods such as natural disasters, there are predicti- 
ons that referral to social work services for children, adults, and families, hidden damages, and accumulated needs will occur when quarantine ends. The anti-coercive social work intervention model requires professionals to ensure that their clients and their health are protected, while on the other hand, the virus is not transmitted. This situation requires social workers to adapt their professional skills to pandemic conditions.

Even though this process is challenging, it continues in periods when direct contact is restricted or even restricted, such as a pandemic. In addition to the needs of people independent of the pandemic, the social and economic difficulties and needs due to the pandemic impose more responsibilities on social work. They endeavor to provide uninterrupted services by responding to the new demands and expectations that arise in society. In this context, social workers must have a minimum knowledge of the cause and symptoms of this disease, primarily to assist clients in the process of the COVID-19 outbreak. The importance of human relations in helping the client is encouraged. Establishing a safe, honest and empathetic relationship in face-to-face professional activities is essential for effective service delivery to the client. However, in such a period when restrictive measures are underway, social workers need to establish a good relationship and maintain this relationship. While social workers protect themselves from the virus, clients also have a responsibility to protect their health. One consequence of the curfew affecting the face-to-face meeting is the limited time the practitioners spend with the client to prevent the transmission of the virus. The client could be contacted over video conferences or telephone facilities. At this point, the hybrid method could be used as the most suitable solution.

As a result, the importance of professional helping professions such as social work has become more evident during the pandemic. Undoubtedly, the pandemic period did not prevent social workers from performing their interventions and even seeking alternative methods following the pandemic rules. The difficulties experienced in this context have led to initiatives at micro, meso, and macro levels for social work, a practice-based profession. These include tackling ethical challenges; quickly adapting to new conditions; lack of information about the symptoms, prevalence, treatment processes, and prevention of the COVID-19 disease; informing the clients, and creating professional practice guides specific to the intervention areas (children, the elderly, hospitals) during 
the pandemic period; anti-oppressive practice; maximizing intersectoral cooperation; working on self-care and psychological resilience; conducting the hybrid application method by increasing the digital skills of the experts and adopting the rights-based application against the possible violations of the restrictions.

\section{Kaynakça / References}

Banks, S., Cai, T., De Jonge, E., Shears, J., Shum, M., Sobočan, A. M., Strom, K., Truell, R., Úriz, M. J., ve Weinberg, M. (2020a). Ethical challenges for social workers during Covid-19: A global perspective. International Federation of Social Workers. https://www.ifsw.org/wp-content/uploads/2020/07/2020-06-30-Ethical-Challenges-Covid19-FINAL.pdf adresinden erişilmiştir.

Banks, S., Cai, T., Jonge, E. D., Shears, J., Shum, M., Sobočan, A. M., Strom, K., Truell, R., Úriz, M. J., ve Weinberg, M. (2020b). Practising ethically during COVID-19: Social work challenges and responses. International Social Work, 1-15. https:/jjournals.sagepub.com/doi/full/10.1177/0020872820949614 adresinden erişilmiştir.

BASW, (2020). Quick guide: Self-care for social workers during covid-19. [online] 20 Kasım 2020 tarihinde https:/wwww.basw.co.uk/quick-guide-self-care-social-workers-duringcovid-19 adresinden erişilmiştir.

Bride, B. E. (2007). Prevalence of secondary traumatic stress among social workers. Social work, 52(1), 63-70.

De Jonge, E., Kloppenburg, R, ve Hendriks, P. (2020). The impact of the COVID-19 pandemic on social work education and practice in the Netherlands. Social Work Education, 39(8), 1027-1036.

Deng, S. (2020). Social resilience construction in the epidemic crisis and social work positioning. Journal of Social Work (China). 287(2).

Dominelli, L., ve Campling J. (2002). Antioppressive social work theory and practice. Macmillan International Higher Education.

Dominelli, L. (2020). Social work during a health pandemic. [Çevrimiçi]. British Association of Social Workers. 6 Kasm 2020 tarihinde https://www.basw.co.uk/system/files/resources/Social\%20Work\%20in\%20Times\%20of\%20the\%20Covid-19\%20Pandemic\%2018\%20March\%202020\%20BASW 0.pdf adresinden erişilmiştir.

Featherstone, B., Gupta, A., Morris, K. ve White, S. (2018). Protecting children: A social model. Bristol: Policy Press. 
Ferguson, H., Pink, S. ve Kelly, L. (2020). How social work and child protection are being creative and helping children and families during COVID-19 and can do so beyond it. 1 Mart2021 tarihinde https://www.researchinpractice.org.uk/children/news-views/2020/august/how-social-work-and-child-protection-are-being-creative-and-helpingchildren-and-families-during-covid-19-and-can-do-so-beyond-it/ adresinden erişilmiştir.

Flynn-O'Brien, K. T., Rivara, F. P., Weiss, N. S., Lea, V. A., Marce-lin, L. H., Vertefeuille, J., ve Mercy, J. A. (2016). Prevalence of physical violence against children in Haiti: A national population- based cross-sectional survey. Child Abuse E Neglect, 51, 154-162. IFSW, (2014). Global definition of the social work profession. https://www.ifsw.org/what-is-socialwork/global-definition-of-social-work/ adresinden erişilmiştir.

Kadushin, A. ve Kadushin G. (2016). Sosyal hizmet görüşme teknikleri. Nika.

Keddell, E. (2020), The case for an inequalities perspective in child protection. Policy Quarterly, 16(1)36-38.

Laird, S. (2008). Anti-oppressive social work: A guide for developing cultural competence. Sage.

Lindo, J., Schaller, J. ve Hansen B. (2013). Economic conditions and child abuse. IZA DPNo. 7355. Bonn: Institute for the Study of Labor. 20 Kasim 2020 tarihinde http://ftp.iza.org/dp7355.pdf adresinden erişilmiştir.

Lu, X., Zhang, L. ve Du H. (2020). SARS-CoV-2 infection in children. N. Engl. J. Med.; 382, 1663-1665.

MEB (2020). Ĕ̈itimde kontrollü normalleşme sürecinde eğitim kurumlarmın açlma ve uygulama kriterler. Basın Açklaması 1 Mart 2021 tarihinde http://www.meb.gov.tr/basinaciklamasi-egitimde-kontrollu-normallesme-surecinde-egitim-kurumlarininacilma-ve-uygulama-kriterleri/haber/22651/tr adresinden erişilmiştir.

Miller, V. J., ve Lee, H. (2020). Social work values in action during covid-19. Journal of Gerontological Social Work, 1-5.

Nelson, B. D., Collins, L., VanRooyen, M. J., Joyce, N., Mukwege, D., ve Bartels, S. (2011). Impact of sexual violence on children in the eastern Democratic Republic of Congo. Medicine, Conflict and Survival, 27, 211-225.

Sağlık Bakanlığı (2020). COVID-19 Bilgilendirme Sayfası. [Çevrimiçi]. Sağlık Bakanlığı. 6 Kasim 2020 tarihinde https://covid19.saglik.gov.tr adresinden erişilmiştir.

Pentini, A. ve Lorenz, W. (2020). The corona crisis and the erosion of "the social": Giving a decisive voice to the social professions. European Journal of Social Work. 13 Temmuz 2020 tarihinde https:/www-tandfonlinecom.ezphost.dur.ac.uk/doi/full/10.1080/13691457.2020.1783215 adresinden erişilmiştir. 
Redondo-Sama, G., Matulic, V., Munté-Pascual, A., ve de Vicente, I. (2020). Social work during the covid-19 crisis: Responding to urgent social needs. Sustainability, 12(20), 8595.

Rubenstein, B. L., ve Stark, L. (2017). The impact of humanitarian emergencies on the prevalence of violence against children: An evidence-based ecological framework. Psychology, Health \& Medicine, 22, 58-66.

Seddighi, H., Salmani, I., Javadi, M.H., ve Seddighi S. (2019). Child abuse in natural disasters and conflicts: A systematic review. Trauma Violence Abuse. https:/journals.sagepub.com/doi/10.1177/1524838019835973

Sheafor, B. W. ve Horejsi, C. J. (2014). Sosyal hizmet uygulaması temel teknikler ve ilkeler, (Çev. B. Çiftçi), Ankara: Nika Yayınevi.

Sosyal Hizmet Uzmanları Dernegi (SHUDER) (2003). Sosyal hizmet mesleğinin etik ilkeleri ve sorumlulukları. Ankara: Evin Yayınları.

Swazoom (2020). Sociaal werk toegevoegd aan lijst cruciale beroepen. Social work added to the list of crucial professions. Retrieved from: Haziran, 2020 tarihinde https://swazoom.nl/nieuws/sociaal-werk-toegevoegd-aan-lijst-cruciale-beroepen adresinden erişilmiştir.

Teo, S.S.S. ve Griffiths, G. (2020), Child protection in the time of COVID-19. J Paediatr Child Health, 56, 838-840. https://doi.org/10.1111/jpc.14916

UNDP (2020). A UN framework for the immediate socio-economic response to COVID-19.6 Kasim 2020 tarihinde https://unsdg.un.org/sites/default/files/2020-04/UN-frameworkfor-the-immediate-socio-economic-response-to-COVID-19.pdf adresinden erişilmiştir.

Wang, G., Zhang, Y., Zhao, J., Zhang, J., ve Jiang F. (2020). Mitigate the effects of home confinement on children during the COVID-19 outbreak. Lancet. 395, 945-7.

WHO (2020). WHO Coronavirus Disease (COVID-19) Dashboard [Çevrimiçi]. 6 Kasım 2020 tarihinde https://covid19.who.int

Wilson, M. (2020). Implications of coronavirus (covid-19) for America's vulnerable and marginalized populations. Social Justice Brief. https://www.socialworkers.org/LinkClick.aspx?fileticket=U7tEKIRldOU\%3D\&portalid=0 adresinden erişilmiştir.

Wu, J., ve McGoogan, J. M. (2020). Characteristics of and important lessons from the coronavirus disease 2019 (COVID-19) outbreak in China: Summary of a report of 72314 cases from the chinese center for disease control and prevention. JAMA, 323(13), 1239-1242. https://doi.org/10.1001/jama.2020.2648 


\section{Kaynakça Bilgisi / Citation Information}

Selçuk, O. (2021). Sosyal hizmet ve covid-19: Salgın sürecinde sosyal hizmet mümkün mü?. OPUS-Uluslararası Toplum Araştırmaları Dergisi, 17(Pandemi Özel Sayıs1), 3745-3763. DOI: 10.26466/opus.829178 